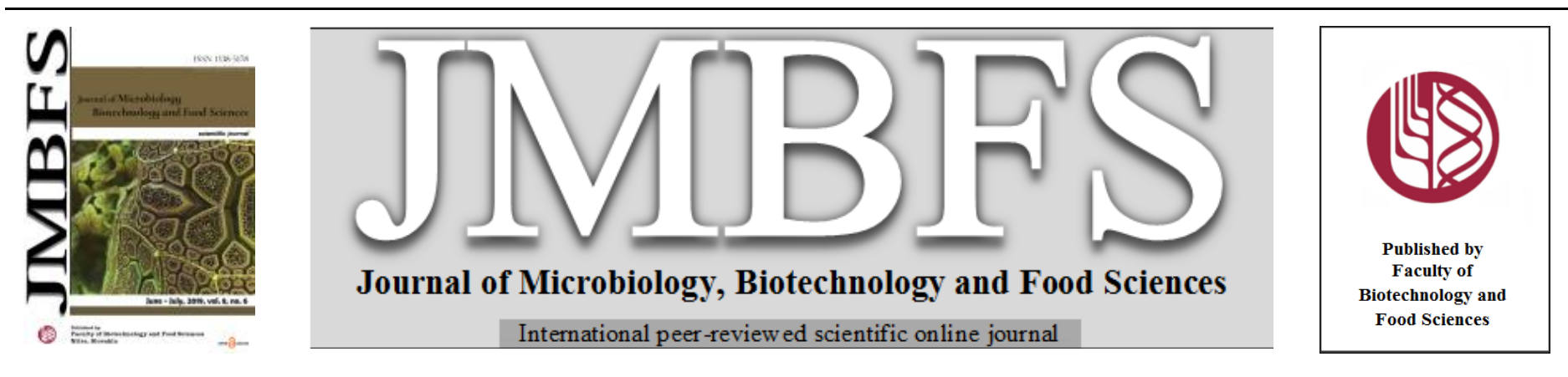

\title{
SYSTEMATIC INVESTIGATION ON PRODUCTION AND QUALITY EVALUATION OF LUGDI: A TRADITIONAL ALCOHOLIC BEVERAGE OF HIMACHAL PRADESH, INDIA
}

\author{
Ashwani Kumar ${ }^{* 1,2}$, V K Joshi ${ }^{1}$ and Vikas Kumar ${ }^{1,2}$ \\ $\operatorname{Address(es):~}$ \\ ${ }^{1}$ Dr. Y S Parmar University of Horticulture and Forestry, Nauni (Solan), Himachal Pradesh, India \\ ${ }^{2}$ Lovely Professional University, Phagwara, Punjab, India
}

*Corresponding author: ashwanichande1480@gmail.com

doi: 10.15414/jmbfs.2019.8.6.1307-1311

\section{ARTICLE INFO}

Received 29. 8. 2018

Revised 6. 2. 2019

Accepted 8. 2. 2019

Published 1. 6. 2019

Regular article

open $\partial_{\text {ACCESS }}$

\begin{abstract}
The present study was aimed to investigate the traditional process of lugdi production, collection of samples and physicochemical analysis of collected samples. The survey revealed that rice (local varieties) or broken rice was used as the main raw material for lugdi preparation. It was further observed that phab was the only inoculum used to carry out the lugdi fermentation. The general production steps in lugdi preparation were cooking of rice (time and water can vary according to place), followed by cooling and mixing of powdered phab. The physicochemical analysis of collected lugdi samples revealed the total soluble solids (TSS) in ranges from 2.5 to $3.9^{\circ} \mathrm{B}$, ethanol 4.61 to $5.68 \%$, lactic acid from 0.83 to $1.15 \%$, total phenols from 127.56-168.54 mg/100 mL. Fourier Transform Infrared Spectroscopy (FTIR) of lugdi samples also confirmed its richness in protein and phenolic compounds. In nutshell, it is concluded that despite its nutritional and health benefits a wide range of variability has been observed in different samples collected from the same production unit, which should be standardized with the involvement of researchers to get a uniform product.
\end{abstract}

Keywords: $p h a b$, rice, ethanol, saccharification, FTIR

\section{INTRODUCTION}

Himachal Pradesh (India) is well known for its topography and culture throughout India where the climatic conditions range from semi-tropical to semiartic; having the altitude from 350 meters to 6975 meters above the sea level These all lead to a wide variation in the living pattern of the hill folks including their costumes and dialects, food pattern, and celebrations; where a wide range of foods (fermented or non-fermented) are prepared and consumed traditionally to adapt to cold climatic conditions (Savitri and Bhalla, 2007). A wide range of fermented foods, both alcoholic (sur, lugdi, ghanti, angoori) and non-alcoholic (sidu, bhatura, seera) have been consumed throughout the state since time immemorial (Bhatia et al., 1977; Thakur et al., 2004; Savitri and Bhalla, 2007; Kanwar et al., 2011; Joshi et al., 2012). Among these, alcoholic beverages are attracting the attention of researchers because of their wide variability, popularity and acceptance among the tribes. However, the production of these beverages is confined to the specific or local areas according to the availability of raw materials such as angoori (grapes) is prepared in Kinnaur: chhang (barley) in Lahulspiti; sur (finger millet) in Kullu, Mandi and Kangra; lugdi (rice) in the Kangra, Kullu and Mandi (Thakur et al., 2004; Senthilkumar, 2009; Kanwar et al., 2011; Joshi et al., 2015). These beverages have an aesthetic appeal as well as a religious and sociocultural value. For instance, sur is offered to local gods like Hurang Narayan and lugdi is sprinkled on the guests to welcome them (Savitri and Bhalla, 2007; Joshi et al., 2015). As per the traditional knowledge available, these beverages possess numerous health benefits such as improving digestion, treatment of stone and jaundice (Das et al., 2012).

Different researchers have already mentioned lugdi in literature as an alcoholic traditional beverage (Bhatia et al., 1977; Thakur et al., 2004; Savitri and Bhalla, 2007; Kanwar et al., 2011) but a detailed study is still lacking which needs to be explored. Lugdi is also known as jhol and is a popular low alcoholic drink in Palampur region of Kangra district. Besides its intoxicating and health properties, it also has socio-cultural value. Hilly areas have witnessed a significant change in alcoholic beverage consumption behaviour; however, this beverage is still popular among local folks. Starting from household, lugdi production has its identity in small-scale industries. Still the uniformity and quality of the product is an issue and scientific interventions are needed to improve the quality and maintain the identity of product for longer time.
Therefore, the present study was designed to point out the basic steps of its production along with its analysis with the aim of fulfilling this research gap.

\section{STUDY SITE}

Palampur is a tehsil and city in the Kangra district of Himachal Pradesh, India. It is situated $25.2 \mathrm{Km}$ west to Kangra city and has an area of $429 \mathrm{Km}^{2}$ including $428.62 \mathrm{Km}^{2}$ rural area and $0.67 \mathrm{Km}^{2}$ of the urban area (Anonymous, 2018a). It extends between $32.11^{\circ} \mathrm{N}$ latitude to $76.53^{\circ} \mathrm{E}$ longitude. The mean annual temperature of Palampur is $19.1^{\circ} \mathrm{C}$, which ranges from a minimum of $9.9^{\circ} \mathrm{C}$ in January to maximum of $27.1^{\circ} \mathrm{C}$ in June (Anonymous, 2018b).

\section{METHODOLOGY}

\section{Survey}

A field survey using an open-ended pretested questionnaire was conducted in the Palampur region (Banodoo, Paraur, Bandla, and Paprola) of the district Kangra, Himachal Pradesh, India. The workers in the production unit were interviewed regarding the production (inocula, processing steps), sale, consumption pattern and the believed positive health benefits (trusted positive medical or health benefits) of lugdi. The customers were also explored for the reasons of lugdi consumption.

\section{Procurement and analysis of samples}

Freshly prepared lugdi was sampled from different lugdi production units in sterilized bottles of $200 \mathrm{~mL}$ capacity and analysed for various quality attributes under laboratory conditions within three days of procurement. Physico-chemical characteristics viz. total soluble solids, total solids, titratable acidity, and $\mathrm{pH}$ were analysed as per the standard methods (AOAC, 1984). Reducing sugar was estimated by di nitro salicylic acid method while, total sugars were determined using phenol sulphuric method (Sadasivam and Manickam, 1991). Ethanol was measured colorimetrically by potassium dichromate method (Caputi et al., 1968). Protein content was determined as per the standard procedure proposed by Lowry (Sadasivam and Manickam, 1991) while, amino acids were measured by the ninhydrin method (Lee and Tunekazu, 1966). Fusel alcohols were measured by the method given by Guymon et al. (1961). Total phenols were measured 
colorimetrically using gallic acid as standard (Singleton and Rossi, 1965), total esters were measured by the method given by Liberty (1961).

\section{Fourier Transform Infrared Spectroscopy (FTIR)}

The collected samples of phab and lugdi were analysed qualitatively using FTIR analyser (Shimadzu 8400S FTIR spectrometer, equipped with $\mathrm{KBr}$ beam splitter). $P h a b$ was ground to a fine powder using lab scale grinder while lugdi was filtered through whatman filter paper and was dried at room temperature $\left(30-35^{\circ} \mathrm{C}\right)$ Approximately $5 \mathrm{mg}$ of each sample along with $5 \mathrm{mg} \mathrm{KBr}$ was used for analysis and FTIR spectrophotometer was operated at a spectral range of $4000-400 \mathrm{~cm}^{-1}$ with a maximum resolution of $-0.85 \mathrm{~cm}^{-1}$. The spectra obtained for the samples were interpreted by following the guidelines given by Stuart (2004)

\section{Sensorial analysis}

To conduct the onsite sensory evaluation of lugdi, a local panel of the consumers was constituted. The panel was provided with a sensory proforma describing the terminology for colour, appearance and taste. The samples of the lugdi were served and the members of panel were asked to give their response on the proforma as per the standard procedure (Joshi, 2006).

\section{Statistical analysis}

The information generated from the survey is presented in tabular form or flowsheets while data obtained from the physico-chemical analysis was analyzed using Graph Pad Prism (La Jolla, CA, USA) software. The results are expressed as means \pm standard deviation of the respective measures.

\section{RESULTS}

\section{Production of lugdi}

As per the information obtained in survey, lugdi has been produced at both household and commercial levels. Commercial production of lugdi was limited to the Palampur region of district Kangra, Himachal Pradesh. In this region four small scale lugdi production units were located at Banodoo, Paprola, Paraur and Bandla. General information of the lugdi production process has been provided in Table 1

Table 1 General information on lugdi preparation in different small scale commercial units of Kangra, Himachal Pradesh $(n=4)$

\begin{tabular}{ll}
\hline Process Variables & Observations \\
\hline Raw material & Broken rice \\
\hline Inoculum type & Phab \\
\hline Utensil used to carry fermentation & Earthen pots \\
\hline Lot preparation & $20-35 \mathrm{~kg}$ \\
\hline Inoculum used & $1-1.5 \%$ or $300-500 \mathrm{~g} / 35 \mathrm{~kg}$ \\
\hline Temperature for inoculum addition & Lukewarm $\left(28-32^{\circ} \mathrm{C}\right)$ \\
\hline Saccharification (duration) & Summer- 2-3 days \\
& Winter- 6-7 days \\
\hline Fermentation (duration) & Summer- $2-3$ days \\
& Winter- 6-7 days \\
\hline Filtration & 1st filtration- with locally made sieve \\
& by cutting and puncturing plastic cans \\
& $\mathbf{2}^{\text {nd }}$ filtration- nylon sieve for fine \\
filtration \\
\hline Recovery & $100-110$ litres per 35 kg batch \\
\hline Bottling & In cleaned glass bottles \\
\hline Sale & $30-40$ INR per 700 mL bottle \\
\hline Storage life & $2-3$ days in summers; 6-7 days in \\
\hline Residue utilization & winters \\
\hline Where, $\mathrm{n}=$ number of lugdi production units covered under study
\end{tabular}

Where, $\mathrm{n}=$ number of lugdi production units covered under study

\section{Raw materials}

The survey revealed that broken rice was used as the main substrate for commercial production of lugdi (Table 1). The reason for the use of broken rice might be the less cost of brokens as compared to head rice. The results of present study were in agreement with Senthilkumar (2009), who reported the use of local rice varieties like Ram juvanae, Totu, Gharsai, Chinnu, Zhinni and Pandpermal in lugdi production.

\section{Inoculum}

Phab, crude inocula was used to carry out the fermentation in all the production units covered under the present study. It was not prepared locally or insitu but was procured from the Khampas of Sidhbaddi (Dharamshala) region of Himachal
Pradesh. These results are in corroboration with the findings of Thakur $\boldsymbol{e t}$ al. (2004); Senthilkumar (2009); Kanwar et al. (2011). In earlier studies, Bhatia et al. (1977); Angmo and Bhalla (2014) have discussed the phab production process in detail.

\section{Production process}

The detailed process of lugdi production has been provided in figure $1(\mathrm{a}, \mathrm{b}$ and c). Depending upon the local demand a batch of $20-35 \mathrm{~kg}$ of rice was being cooked in a big vat (Figure 1b) on a traditional wooden chullah or gas stove to a point of softness except the Paprola unit where rice was overcooked till the browning of the outer layer to impart good colour and flavour in the final product. The development of colour and flavour might have been due to the caramelization of sugars as the decomposition of sugars results in the formation of volatile and brown-coloured compounds (Kroh, 1994). The cooked rice was spread in a thin layer and cooled to about $28-32^{\circ} \mathrm{C}$. Phab granules were ground to a fine powder and mixed uniformly at the rate of $350 \mathrm{~g}-500 \mathrm{~g}$ per $35 \mathrm{~kg}$ of cooked and cooled rice. The prepared mixture was filled in pre-sterilized earthen pots ( $20 \mathrm{~L}$ approx.) with the capacity of $1 / 2^{\text {nd }}-3 / 4^{\text {th }}$ of total volume, capped tightly with clothes and covered with gunny bags or woollen clothes to provide the required incubation temperature to facilitate the saccharification. The saccharification was allowed for 2-3 days in summers and 6-7 days in winters or until the mixture was converted to a cream-like slurry. After the completion of saccharification, the slurry was transferred $(3-4 \mathrm{~kg})$ to sterilised earthen pots $(20$ $\mathrm{L}$ approx.). To the slurry, water was added up to the brim and the mixture was allowed to ferment (2-3 days during summers and 6-7 days in winters). The increased fermentation rate during the summers might have been due to the shortening of lag phase as the lag phase decreases with increase in temperature (Merrit, 1966). During fermentation, the mouth of the pot was left uncovered and the absence of air bubbles on the top of the pot was used as an indicator for completion of fermentation.

\section{Filtration}

After completion of fermentation, the fermented material was filtered to separate lugdi from the spent material. The filtration was a two-step process involving coarse and fine filtration. Coarse filtration was carried out with a large sieve made by cutting plastic cans from one side and engraving holes on the other side (Figure 1c). It was followed by a fine filtration with a fine mesh strainer to get the clear product, which was further filled, into pre-washed glass bottles.

\section{Sensorial analysis}

Onsite sensory analysis of the samples revealed that product had a turbid appearance with colour ranging from white to yellowish white (Table 2). The turbid appearance might be due to the presence of unfermented starch in the drink as starch produces a turbid solution (Sandhu and Singh, 2007) whereas the difference in colour might be due to the caramelization of rice as discussed earlier. The flavour of collected samples varied from a sweet alcoholic to sour alcoholic depending on the freshness of the sample i.e. freshly prepared samples had a sweet alcoholic taste whereas stored samples were sour alcoholics (Table 2). The development of sour taste might be due to the growth of lactic acid along with fermentation as the phab contains a mixed microflora i.e. Saccharomyces cerevisiae and Lactobacillus species (Joshi and Sandhu, 2000; Thakur et al., 2004; Joshi, 2016).

\section{End use}

As per the survey, it was observed that lugdi was not pasteurized and had a shelf life of 2-3 days in summers and 6-7 days in winters. The reason for not pasteurizing lugdi might be the lack of pasteurization facilities at the production units. It was also observed in the survey that product had a good demand in Palampur region and was sold onsite at a sale price of INR $30-40$ per $750 \mathrm{~mL}$ bottle. The spent material was used as a feed for the mules (Figure 1c).

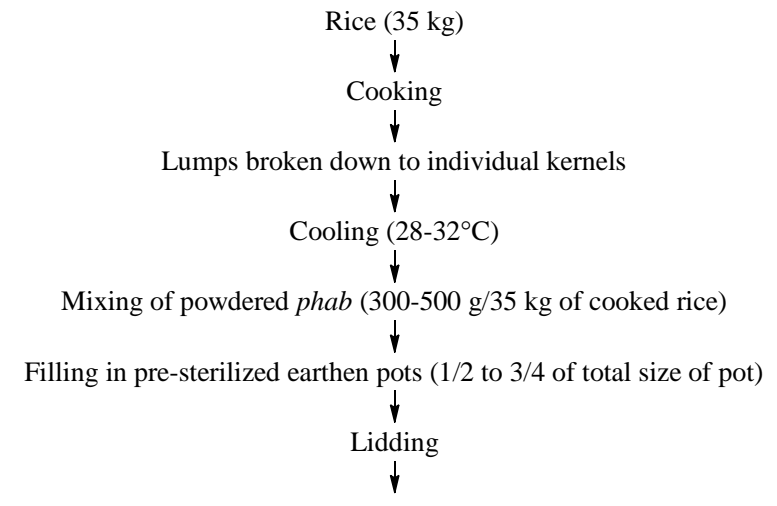


Fermentation

(2-3 days in summer and 6-7 days in winter or till a creamy product is obtained)

$$
\downarrow
$$

Transfer 3-4 $\mathrm{kg}$ of this creamy product to other pots

$$
\downarrow
$$

Filling the pot with water

$$
\downarrow
$$

Fermentation

(2-3 days in summer and 6-7 days in winter)

$$
\begin{gathered}
\downarrow \\
\text { Filtration } \\
\downarrow \\
\text { Filled into bottles } \\
\downarrow \\
\text { Consumption }
\end{gathered}
$$

(Fresh or within 2-3 days of production)

Figure 1a Flow diagram of the traditional technology of the lugdi production as per the information gathered from lugdi production units

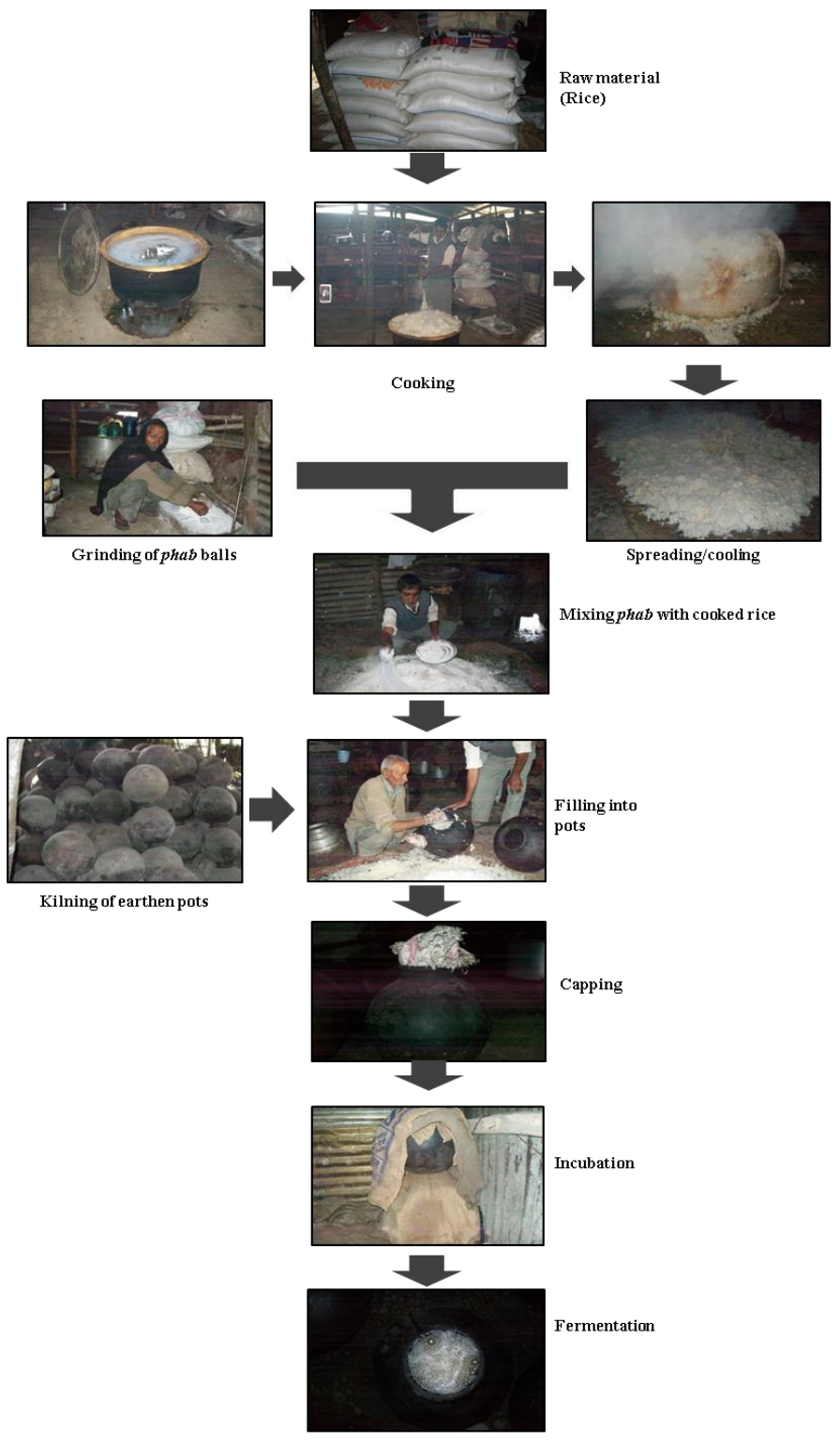

Figure 1b Pictorial representation of lugdi production process at small-scale commercial units

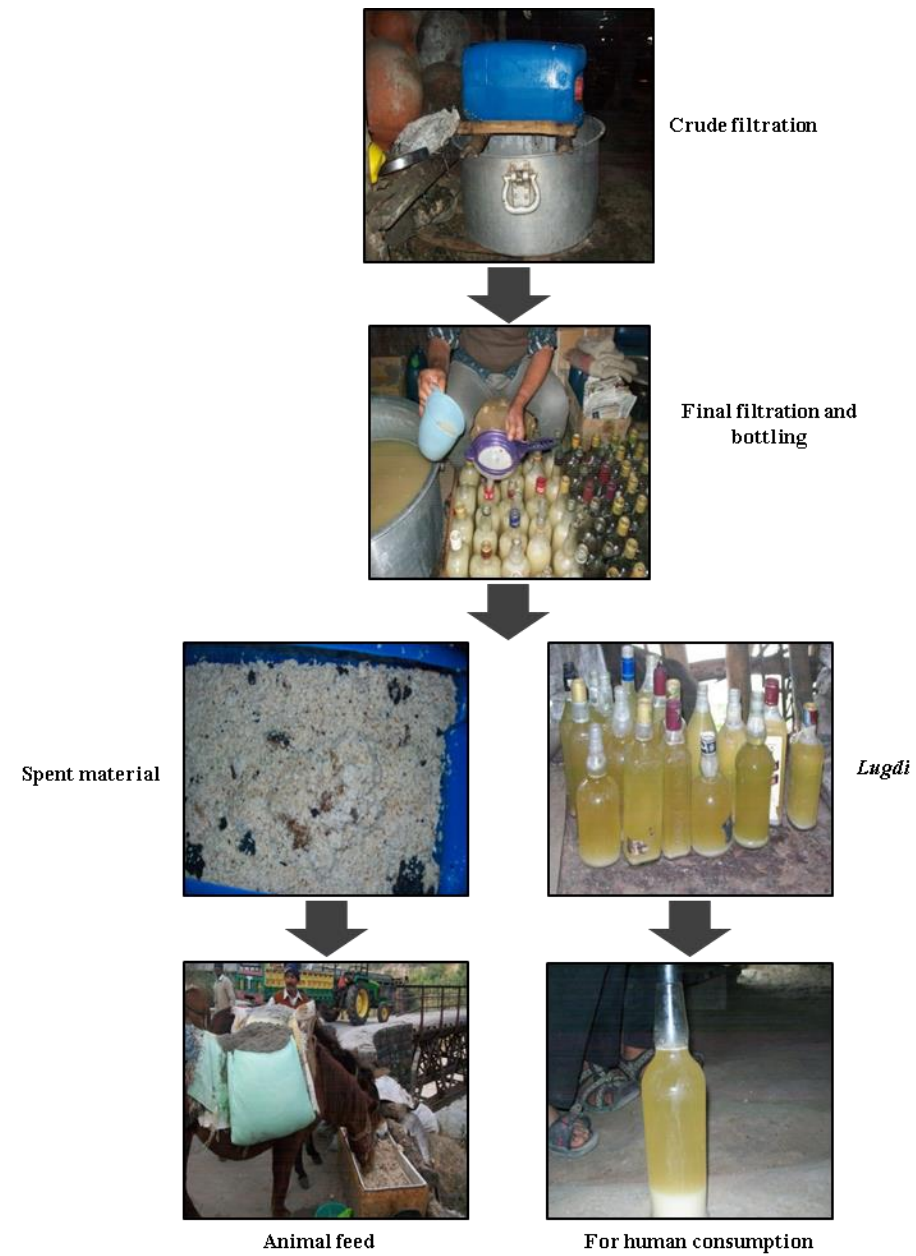

Figure 1c Pictorial presentation of filtration process and end-use of lugdi

Table 2 Sensory attributes of the collected lugdi samples

\begin{tabular}{ll}
\hline Sensory Parameters & Observation \\
\hline Colour & White to yellowish white \\
\hline Appearance & $\begin{array}{l}\text { Turbid with starch settled at the } \\
\text { bottom of bottle }\end{array}$ \\
\hline Aroma & $\begin{array}{l}\text { Acido-alcoholic (mixture of acid and } \\
\text { alcohol) }\end{array}$ \\
\hline Taste & Sour with the lingering taste of starch \\
\hline
\end{tabular}

Table 3 Physico-chemical attributes of collected lugdi samples

\begin{tabular}{lll}
\hline Parameters & Range & Mean Values \\
\hline Total solids $(\%)$ & $6.3-7.8$ & $6.83 \pm 0.35$ \\
\hline TSS $\left({ }^{\circ} \mathrm{B}\right)$ & $2.5-3.9$ & $3.03 \pm 0.75$ \\
\hline $\begin{array}{l}\text { Reducing sugars } \\
(\%)\end{array}$ & $0.15-0.42$ & $0.28 \pm 0.08$ \\
\hline $\begin{array}{l}\text { Total sugars } \\
(\%)\end{array}$ & $0.48-0.72$ & $0.68 \pm 0.19$ \\
\hline $\begin{array}{l}\text { Ethanol } \\
(\% \mathrm{v} / \mathrm{v})\end{array}$ & $4.61-5.68$ & $5.14 \pm 0.53$ \\
\hline $\begin{array}{l}\text { Colour } \\
(\text { O.D. })\end{array}$ & $0.362-0.380$ & $0.371 \pm 0.09$ \\
\hline pH & $2.82-3.55$ & $3.08 \pm 0.41$ \\
\hline Acidity $(\%$ as lactic acid) & $0.83-1.15$ & $0.97 \pm 0.18$ \\
\hline $\begin{array}{l}\text { Total proteins } \\
(\mathrm{mg} / 100 \mathrm{~mL})\end{array}$ & $568.42-618.24$ & $592.32 \pm 24.97$ \\
\hline $\begin{array}{l}\text { Free amino acids } \\
(\mathrm{mg} / 100 \mathrm{~mL})\end{array}$ & $272.45-315.68$ & $295.5 \pm 21.75$ \\
\hline Total phenols $(\mathrm{mg} / 100 \mathrm{~mL})$ & $127.56-168.54$ & $148.58 \pm 20.51$ \\
\hline Total esters $(\mathrm{mg} / 100 \mathrm{~mL})$ & $85.34-108.78$ & $96.93 \pm 11.72$ \\
\hline Fusel alcohols $(\mathrm{mg} / 100 \mathrm{~mL})$ & $22.48-32.94$ & $27.59 \pm 5.23$ \\
\hline
\end{tabular}

\section{Physicochemical characteristics of collected lugdi samples}

The collected lugdi samples were analysed for the different physicochemical parameters (Table 3 ), which revealed a wide variation even among the batches of 
the product prepared in the same unit. This variation might be due to the nonstandardized process and recipe used for lugdi production. Among the collected samples, total solids ranged from $6.3 \%$ to $7.8 \%$, total soluble solids ranged from 2.5 to $3.9^{\circ} \mathrm{B}$, total sugars were in between $0.48 \%$ to $0.72 \%$ and reducing sugars was in the range of $0.15 \%$ to $0.42 \%$. The results of these parameters were in agreement with the results reported by Senthilkumar (2009). The ethanol content of the product varied from $4.61 \%$ to $5.68 \%$. Kanwar et al. (2011) had reported similar ethanol content in lugdi samples collected from LahulSpiti, Himachal Pradesh (India). However, Thakur et al. (2004) had reported a higher ethanol content of $8.5 \%$ in lugdi samples collected from Kullu district of Himachal Pradesh (India). Analysis also revealed $\mathrm{pH}$, titratable acidity, protein total phenols, esters and fusel alcohol in the ranges of 2.82 to $3.55,0.83$ to $1.15 \%$ as lactic acid, 568.42 to $618.24 \mathrm{mg} / 100 \mathrm{~mL}, 49.1$ to $100.7 \mathrm{mgGAE} / 100 \mathrm{~g}, 85.34$ to $108.78 \mathrm{mg} / \mathrm{L}$ and 22.48 to $32.94 \mathrm{mg} / \mathrm{L}$, respectively. $\mathrm{A} \mathrm{pH}$ of 3.21 and titratable acidity of $0.20 \%$ has been reported by Tamang and Thapa (2006) in bhattijannr (a fermented rice beverage of north India). Chiang et al. (2006) reported a $\mathrm{pH}$ of 3.4 and acidity of $0.86 \%$ in tapai (an alcoholic beverage prepared from glutinous rice). Phab might be the major source of phenolics in the lugdi as phab consists of several herbs (as information gained during the survey).
Esters are synthesized by yeasts during fermentation via several complex pathways (Saerens et al., 2010). The wide variation in the physicochemica attributes of the collected samples might be due to the non-standardized recipe and local variation in process of the lugdi production.

\section{FTIR characterization}

FTIR spectrophotometer is among one of the most important analytical tools used to study physiochemical and conformational properties of wide range of samples including food (Stuart, 2004). The infrared spectra of phab and lugdi have been provided in (Figure 2a and 2b). The area of the respective peaks (phab and lugdi) is tabulated in Table 4. FTIR wave numbers are associated with the absorption bands of the compounds present in the foods. The interpretation of the peaks confirmed the presence of numerous nutritional and phytochemical compounds including sugars, amino acids, amides, aliphatic compounds, phenols and alcohols. Panda et al. (2014) reported similar functional compounds on FTIR analysis of bael wine.

Table 4 FTIR spectra of phab and lugdi

\begin{tabular}{|c|c|c|c|c|c|c|}
\hline \multirow{2}{*}{$\begin{array}{l}\text { Sr. } \\
\text { No. }\end{array}$} & \multicolumn{3}{|l|}{ Phab } & \multicolumn{3}{|l|}{ Lugdi } \\
\hline & Peak & Area & Compound & Peak & Area & Compound \\
\hline 1 & 420.5 & 19.14 & $\mathrm{KBr}$ & 514.05 & 7.486 & $\mathrm{KBr}$ \\
\hline 2 & 521.76 & 48.691 & $\mathrm{KBr}$ & 1034.84 & 33.895 & $\begin{array}{l}\text { Alcohols, } \mathrm{C}=\mathrm{C}-\mathrm{CH}_{2}-\mathrm{OH}, \mathrm{C}-\mathrm{O} \text { stretch } \\
\text { (phenolics) }\end{array}$ \\
\hline 3 & 575.77 & 48.283 & $\mathrm{NaCl}$ & 1254.74 & 6.156 & $\begin{array}{l}\text { Alcohols, phenols, Ar-O-H, C-O } \\
\text { stretch }\end{array}$ \\
\hline 4 & 762.87 & 63.167 & $\begin{array}{l}\text { Aromatic compounds } \mathrm{C}- \\
\mathrm{H} \text { bend }\end{array}$ & 1463.06 & 6.841 & Alanine, valine \\
\hline 5 & 860.28 & 40.29 & $\begin{array}{l}\beta \text {-D-Sucrose, } \beta \text {-D- } \\
\text { glucopyranoside }\end{array}$ & 1547.93 & 7.554 & Protein amide II \\
\hline 6 & 930.68 & 50.758 & $\begin{array}{l}\text { Carboxylic acids } \mathrm{C}-\mathrm{O}-\mathrm{H} \\
\text { out-of-plane bending }\end{array}$ & 1647.26 & 8.821 & Proteins \\
\hline 7 & 1021.34 & 171.132 & $\begin{array}{l}\text { Phenols C-O stretching, } \\
\mathrm{O}-\mathrm{H} \text { aromatic }\end{array}$ & 1739.85 & 5.625 & $\begin{array}{l}\text { Carbohydrates, aldehydes and ketones } \\
\text { aliphatic aldehyde } \mathrm{C}=\mathrm{O} \text { stretching }\end{array}$ \\
\hline 8 & 1154.43 & 73.021 & Cellulose & 1835.33 & 3.878 & $\mathrm{C}=\mathrm{O}$ stretching (carbonyl group) \\
\hline 9 & 1458.23 & 20.931 & Alanine, valine & 2361.91 & 10.574 & $\begin{array}{l}\mathrm{X}-\mathrm{H} \text { stretching, } \mathrm{X} \text { is phosphorus or } \\
\text { silicon }\end{array}$ \\
\hline 10 & 1539.25 & 18.343 & $\begin{array}{l}\text { Lysine, protein, amide } \\
\text { II }\end{array}$ & 2927.08 & 31.278 & $\begin{array}{l}\text { O-H stretching (carboxylic acids), } \\
\text { aliphatic compounds }\end{array}$ \\
\hline 11 & 1651.12 & 21.561 & Proteins, amide I & 3619.54 & 7.21 & O-H stretching (phenols) \\
\hline 12 & 2362.88 & 41.079 & $\begin{array}{l}\mathrm{X}-\mathrm{H} \text { stretching, } \mathrm{X} \text { is } \\
\text { phosphorus or silicon }\end{array}$ & 3743.96 & 10.776 & $\mathrm{O}-\mathrm{H}$ stretching (water) \\
\hline 13 & 2927.08 & 173.138 & $\begin{array}{l}\text { O-H stretching } \\
\text { (carboxylic acids), } \\
\text { aliphatic compounds }\end{array}$ & 3848.12 & 3.638 & $\mathrm{X}-\mathrm{H}$ stretching region \\
\hline 14 & 3342.75 & 5.326 & $\mathrm{O}-\mathrm{H}$ stretching (water) & & & \\
\hline
\end{tabular}

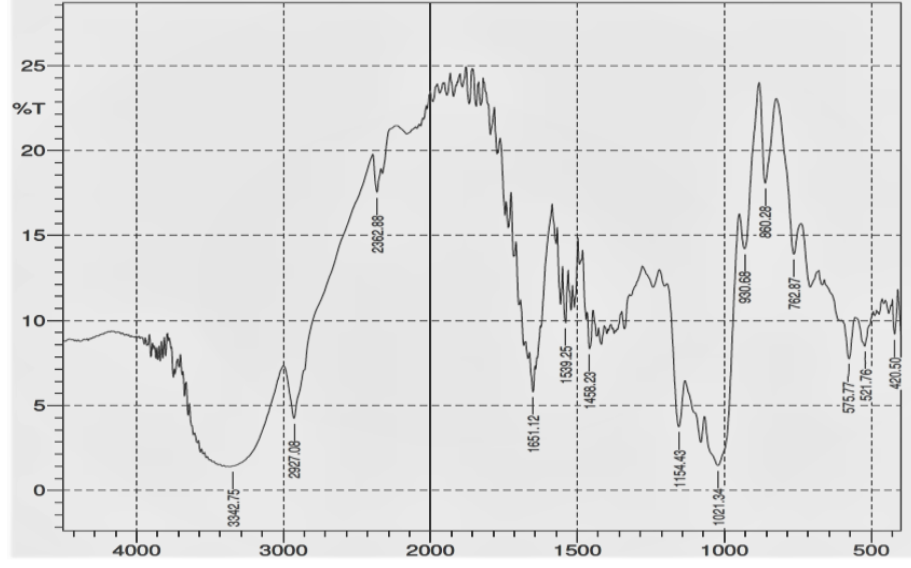

Figure 2a FTIR spectra for phab

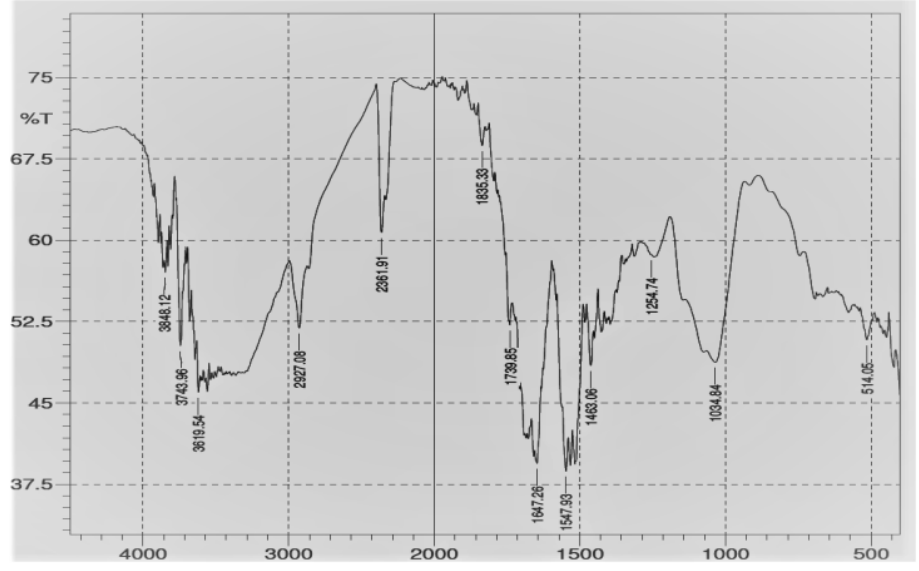

Figure 2b FTIR spectra for lugdi

\section{CONCLUSION}

Production and consumption of lugdi is an inherent part of the traditional culture of Palampur, Himachal Pradesh, India. Physicochemical and FTIR analysis of the product confirmed that it is a rich source of nutrients and phytochemicals like amino acids and phenolics, which strengthen its traditional claim of numerous health benefits. However, the availability of the commercial beverages and 
reluctance of the new generation to get involved in the production of these beverages has put the traditional heritage under threat. It was concluded from the present study that the lugdi production process was not standardized and varied from place to place. Physicochemical analysis has also revealed a wide variation among the composition of the samples. Therefore, there is a need for an intervention by regulatory bodies to standardize the recipe and production process to produce a uniform product in terms of ethanol and other alcohols. This could also help in shielding the rich traditional heritage of the state.

\section{CONFLICT OF INTEREST}

There is no conflict of interest among authors.

Acknowledgements: Authors are thankful to the owners and workers of the small-scale lugdi production units located in Banodoo, Paraur, Bandla, and Paprola, Palampur, Himachal Pradesh for sharing their knowledge, allowing working with them and photographing the lugdi production process. Authors are also thankful to local folks for sharing their knowledge on the lugdi production process and believed health benefits.

\section{REFERENCES}

ANGMO, K., BHALLA, T. C. 2014. Preparation of Phabs-an indigenous starter culture for production of traditional alcoholic beverage, Chhang, in Ladakh. Indian Journal of Traditional Knowledge, 13(2), 347-351.

ANONYMOUS. Climate Data. 2018a. https:/len.climatedata.org/location/49025/.

ANONYMOUS. Palampur Monthly Climate Averages. 2018b https://www.worldweatheronline.com/lang/en-in/palampur-weather-

averages/himachal-pradesh/in.aspx.

AOAC. 1984. Official Methods of Analysis. Association of Official Analytical Chemists. $14^{\text {th }}$ ed. (Washington, DC).

BHATIA, A. K., SINGH, R. P., ATAL, C. K. 1977. "Chhang”- the fermented beverage of Himalyan folk. Indian Food Packer, 32-39.

CAPUTI, A., MASAO, U., THOMAS, B. 1968. Spectrophotometeric determination of ethanol in wine. American Journal of Enology and Viticulture, 26, 201-207.

CHIANG, Y. W., CHYE, F. Y., MOHD, I. A. 2006. Microbial diversity and proximate composition of Tapai, A Sabah's fermented beverage. Malaysian Journal of Microbiology, 2(1), 1-6.

DAS, A. J., DEKA, S. C., MIYAJI, T. 2012. Methodology of rice beer preparation and various plant materials used in starter culture preparation by some tribal communities of North-East India: A survey. International Food Research Journal, 19, 101-107.

GUYMON, J. F., INGRAHAM, J. E., CROWELL, E. R. 1961. Influence of aeration upon the formation of higher alcohols by yeasts. American Journal of Enology and Viticulture, 2(2), 60-66.

JOSHI, V. K. 2006. Sensory Science: Principles and Applications in Evaluation of Food. Agro-Tech Publishers, Udaipur, 527p. ISBN-10: 8183210538.

JOSHI, V. K., KUMAR, A., THAKUR, N. S. 2015. Technology of preparation and consumption pattern of traditional alcoholic beverage 'Sur' of Himachal Pradesh. International Journal of Food and Fermentation Technology, 5(1), 7582. https://dx.doi.org/10.5958/2277-9396.2015.00011.2

JOSHI, V. K. 2016. Indigenous Fermented Foods of South Asia. Rob Nout and Prabir Sarkar, Series Eds, The Fermented Foods and Beverages Series, CRC Press, Roca, Florida, USA, 851p. ISBN 9781466565302 - 629.

JOSHI, V. K., SANDHU, D. K. 2000. Quality evaluation of naturally fermented alcoholic beverages, Microbiological examination of source of fermentation and ethanol productivity of the isolates. Acta Alimentria, 29(4), 323-334 https://doi.org/10.1556/AAlim.29.2000.4.2

JOSHI, V. K., GARG, V., ABROL, G. S. 2012. Indigenous fermented foods. In: Food biotechnology: principles and practices, V K Joshi and R S Singh eds., I K International Publishing House, New Delhi, India, 337-374. ISBN : 9381141495 , 9789381141496.

KANWAR, S. S., GUPTA, M. K., CHHAYA, K., PROMILA, K. 2011. Cereal based traditional alcoholic beverages of Lahul and Spiti area of Himachal Pradesh. Indian Journal of Traditional Knowledge, 10(3), 251-257.

KROH, L. W. 1994. Caramelisation in food and beverages. Food Chemistry, 51(4), 373-379.

LEE, Y. P., TUNEKAZU, T. 1966. An improved colorometric determination of amino acids with the use of ninhydrin. Analytical Biochemistry, 14(1), 71-77.

LIBERTY, V. 1961. Ester determination and their application to wine. M.Sc. Thesis, University of California, Davis, Macmillan, New York.

MERRIT, N. R. 1966. The influence of temperature on some properties of yeast. Journal of the Institute of Brewing, 72(4), 374-383.

PANDA, S. K., SAHU, U. C., BEHERA, S. K., RAY, R. C. 2014. Bioprocessing of bael [Aegle marmelos L.] fruits into wine with antioxidants. Food Bioscience, 5, 34-41. https://doi.org/10.1016/j.fbio.2013.10.005

SAVITRI., BHALLA, T. C. 2007. Traditional fermented foods and beverages of Himachal Pradesh. Indian Journal of Traditional Knowledge, 12(1), 17-24.
SADASIVAM, S., MANICKAM, A. 1991. Biochemical methods. New Age International (P) Limited, Publishers, New Delhi. ISBN-10: 8122421407.

SAERENS, M. G., DELVAUX, F. R., VERSTREPEN, K. J., THEVELEIN, J. M. 2010. Production and biological function of volatile esters in Saccharomyces cerevisiae. Microbial Biotechnology, 3(2), 165-177. https://dx.doi.org/10.1111\%2Fj.1751-7915.2009.00106.x

SANDHU, K. S., SINGH, N. 2007. Some properties of corn starches II: Physicochemical, gelatinization, retrogradation, pasting and gel textural

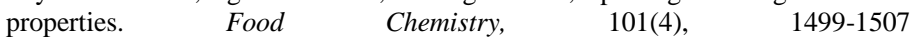
https://dx.doi.org/10.1016/j.foodchem.2006.01.060

SENTHILKUMAR, R. 2009. Quality evaluation of rice beer (jhol) prepared from selected rice varieties of Himachal Pradesh. M.Sc. thesis, Dept. of Food Science and Nutrition, CSKHPKV, Palampur, India.

SINGLETON, V. L., ROSSI, J. A. 1965. Colorimetry of total phenolics with phosphomolybadic phosphotungstic acid reagents. American Journal of Enology and Viticulture, 16(3), 144-158.

STUART, B. 2004. Infrared Spectroscopy: Fundamentals and Applications. John Wiley \& Sons, Inc. 203. ISBN:9780470011140. https://doi.org/10.1002/0470011149

TAMANG, J. P., THAPA, S. 2006. Fermentation dynamics during production of Bhaati Jaanr, a traditional fermented rice beverage of the Eastern Himalayas Food Biotechnology, 20(3), 251-261. https://doi.org/10.1080/08905430600904476

THAKUR, N., BHALLA, S., CHAND, T. 2004. Characterization of some traditional fermented foods and beverages of Himachal Pradesh. Indian Journal of Traditional Knowledge, 3(3), 325-335. 